\title{
Pharmacognostic Studies on Methanolic Extract of Leaves of Vitex negundo Linn
}

\author{
Kiran Sharma*, Manish Yadav, Kavita Attri
}

Kiran Sharma*, Manish Yadav, Kavita Attri

SGT College of Pharmacy, Gurugram, Haryana-122505, INDIA.

\section{Correspondence}

\section{Kiran Sharma}

SGT College of Pharmacy, Gurugram, Haryana- 122505, INDIA.

E-mail: kiransharmapharma@gmail.com

History

- Submission Date: 29-12-2019;

- Review completed: 05-02-2020;

- Accepted Date: 20-02-2020.

DOI : 10.5530/pj.2020.12.83

Article Available online http://www.phcogj.com/v12/i3

Copyright

(C) 2020 Phcogj.Com. This is an openaccess article distributed under the terms of the Creative Commons Attribution 4.0 International license.

\section{ABSTRACT}

Vitex negundo Linn (verbenaceae), known as Nirgundi is important medicinal plant with variety of phytoconstituents having significant pharmacological activities. It has antiinflammatory, analgesic, anti-histaminic, anti-oxidant, anti-bacterial, hepatoprotective, antiimplantation, laxative, larvicidal, anti-arthritic, anticonvulsant and effective against snake venom activity. Two compounds namely vitexin and negundoside are reported to have anticancer and hepatoprotective activity respectively. For safe and effective use of herbal drugs in a formulation, proper standardization of herbal drugs is necessary. So, in this research paper basic pharmacognostic studies on Vitex negundo leaf extract like physicochemical parametersash values and extractive values, Fluorescence analysis, phytochemical screening, TLC profile with different solvent systems, behavior with different reagents and metal analysis was done. The findings throw light on preliminary standardization of this important medicinal plant. Key words: Vitex negundo (VN), Ash values, Extractive values, Fluorescence analysis, TLC.

\section{INTRODUCTION}

Vitex negundo Linn., belonging to family Verbenaceae is commonly known as Nirgundi. The white flowered variety is known as Sinduvaara, whereas the blue flowered variety is known as Nirgundi or Sephaali. The Leaves of Vitex negundo (VN) contain irridoid glycosides like negundoside and flavonoids such as vitexin, which is a flavonol glycoside besides casticin and the glycosides, luteolin-7-glucoside and a-Dglucoside of tetrahydroxy monomethoxy flavones. Also, two pentacyclic triterpenoids, betulinic acid and ursolic acid, along with an aliphatic alcohol, $\beta$-sitosterol and p-hydroxybenzoic acid have been isolated from leaves. Dried powder of roots contain hentriacontane and stigmasterol. The seeds contain p-hydroxybenzoic acid, glucose and the triterpene vitextriterpene. ${ }^{1-3}$ The water extract of the leaves, when administered to rats, exhibited anti-inflammatory, analgesic and antihistaminic activity. ${ }^{4-6}$ The Vitex negundo leaf extract is known to exhibit antioxidant activity. ${ }^{7}$ The methanol, ethanol, petroleum ether and chloroform extract of leaves and bark of VN exhibited significant antibacterial activity. $^{8}$ The active constituent negundoside isolated from leaves of $\mathrm{VN}$ showed hepatoprotective activity against carbon tetrachloride using human liver cells. ${ }^{9-11}$ Research has also proved the antiimplantation effect of $\mathrm{VN} .^{12}$ The crude aqueous extract of $\mathrm{VN}$ are known to produce significant laxative activity in a dose dependant manner. ${ }^{13}$ Vitex negundo is also known to attenuate calpain activation and catractogenesis in selenite induced cataract. ${ }^{14}$ The petroleum ether extract of VN served as a potent larvicidal agent and also acted as a promising repellant against various adult vector mosquitoes. ${ }^{15}$ It has been also found that $\mathrm{VN}$ extract produce reduction of oxidative stress. ${ }^{16}$
The methanol extract of $\mathrm{VN}$ showed significant anti-arthritic activity in Complete Freund's adjuvant induced paw edema in rats. ${ }^{17}$ The methanol extract of $\mathrm{VN}$ showed anticonvulsant activity. ${ }^{18}$ The $\mathrm{VN}$ root extract significantly acted against snake venom. ${ }^{19}$

\section{MATERIALS AND METHODS}

\section{Collection and authentification of plant}

The plant material of $\mathrm{VN}$ was collected from plantation field been situated in a small village called as Shiroor, $60 \mathrm{Kms}$ from Pune and the voucher specimen (08-123) was kept at departmental herbarium of ARI. The plant material was cleaned and dried in the shade and powdered to 40 mesh and stored in an airtight container at $25^{\circ} \mathrm{C}$.

\section{Extraction of plant}

VN leaves were washed and dried at $55^{\circ} \mathrm{C}$ in an air dryer for $48 \mathrm{~h}$. Dried plant material was powdered separately with a Wiley mill (model- $4276 \mathrm{M}$, Thomas, Scientific, USA) to pass a 20 mesh sieve and stored and stored in a sealed plastic bag. About $500 \mathrm{mg}$ of various powders were taken in a $5 \mathrm{ml}$ volumetric flask, mixed with $5 \mathrm{ml}$ of methanol and vortexed for two minutes followed by sonication $(33 \mathrm{MHz}$, Roop telesonic, India) at room temperature for min. The process was repeated thrice for complete extraction. After sonication methanolic extracts were combined and evaporated to dryness in vacuo. Dried extract was obtained as $13.1 \mathrm{~g}$.

\section{Physico-chemical analysis}

The Physicochemical analysis i.e. percentage of ash values and extractive values were performed according to the official methods prescribed in Indian Pharmacopeia, 1996 and the WHO guidelines on quality control methods for medicinal plant

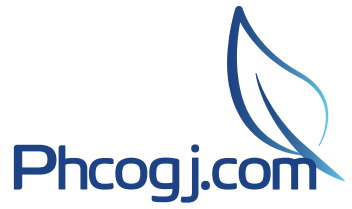

Cite this article: Sharma K, Yadav M, Attri K. Pharmacognostic Studies on Methanolic Extract of Leaves of Vitex negundo Linn. Pharmacog J. 2020;12(3):551-6. 
materials. ${ }^{20,21}$ Fluorescence analysis was carried out according to the method of Chase and Pratt (1949) and Kokoski, et al. (1958). ${ }^{22,23}$ Preliminary phytochemical screening was carried out using standard procedures described by Kokate (1986) and Harborne (1998)..$^{24,25}$ For performing the TLC, leaves were extracted with various solvents in the order of increasing polarities such as carbon tetrachloride, benzene, petroleum ether, ethyl acetate, chloroform, acetone, methanol, ethanol and water so as to obtain all the non-polar, semi-polar and polar constituents that are soluble in these solvents. So, all these extracts of VN leaves were used for estimation by TLC method, so that we can have an idea about the polarity and number of constituents present in these extracts.

\section{RESULTS AND DISCUSSIONS}

\section{Physicochemical studies}

VN was analyzed for moisture content, total ash, water insoluble ash, acid insoluble ash which gives an idea about amount of organic and inorganic constituents present in the samples. Also foaming index, swelling index, loss on drying, $\mathrm{pH}$ and electrical conductivity studies were also performed. These studies give an overview of amount of saponins, moisture content, nature of salt and ions present in the sample Table 1.

\section{Extractive values}

VN leaf extract gives different range of yield in different solvents. The highest yield was obtained in water extract and least yield was obtained in petroleum ether extract. The results are shown in Table 1.

\section{Phytochemical screening}

Phytochemical screening proved that VN leaf extracts has alkaloids, glycosides, flavonoids, fixed oils, carbohydrates, amino acids, terpenoids and steroids. Hence, the phytochemical screening gave an idea about the various classes of chemical compounds present in different solvents Table 2.

\section{TLC behavior of VN leaves}

The purpose behind performing the TLC of each extract was to have an idea about the no. of components in each solvent's extract and $\mathrm{R}_{\mathrm{f}}$ values were determined. The $\mathrm{R}_{\mathrm{f}}$ value of 0.2 confirmed the presence of marker compound as shown in Table 3 as reported by Sharma et al. ${ }^{26}$

\section{Fluoroscence behavior of VN leaf extracts}

The fluorescence of VN leaf extract with different solvents were determined under visible, short and long UV light as mentioned in

Table 1: Physicochemical parameters of $V$. negundo leaves.

\begin{tabular}{ccc}
\hline S.No. & Parameters & Leaf \\
\hline 1. & Total Ash & 0.934 \\
2. & Acid insoluble ash & 0.857 \\
3. & Water soluble ash & 0.077 \\
4. & Loss on drying at $110^{\circ} \mathrm{C}$ & 5.60 \\
5. & Foaming index & 1.4 \\
6. & Swelling index & 0.1 \\
7. & $\mathrm{pH}(2 \%$ w/v) & 5.12 \\
8. & Electrical conductivity & 2.60 \\
& Extractive values & \\
9. & Cyclohexane & 0.068 \\
10. & Carbon tetrachloride & 0.062 \\
11. & Petroleum ether & 0.039 \\
12. & Chloroform & 0.098 \\
13. & Acetone & 0.143 \\
14. & Ethanol & 0.376 \\
15. & Methanol & 0.437 \\
16. & Ethyl acetate & 0.093 \\
17. & Water & 0.420 \\
18. & Benzene & 0.032 \\
\hline
\end{tabular}

Table 2: Phytochemical screening of VN leaves extract.

\begin{tabular}{lccc}
\hline Chemical test & Pet ether extract & Alcohol extract & $\begin{array}{c}\text { Aqueous } \\
\text { extract }\end{array}$ \\
\hline Alkaloids & - & + & - \\
Dragendorf's & - & + & - \\
Mayer's & - & + & - \\
Hager's & - & & + \\
Glycosides & - & - & + \\
Fehling's & - & - & - \\
Legal & - & - & - \\
Keller Killiani & - & & + \\
Tannins & - & - & + \\
Phenazone & - & + & \\
Lead acetate & & & \\
Carbohydrates & &
\end{tabular}




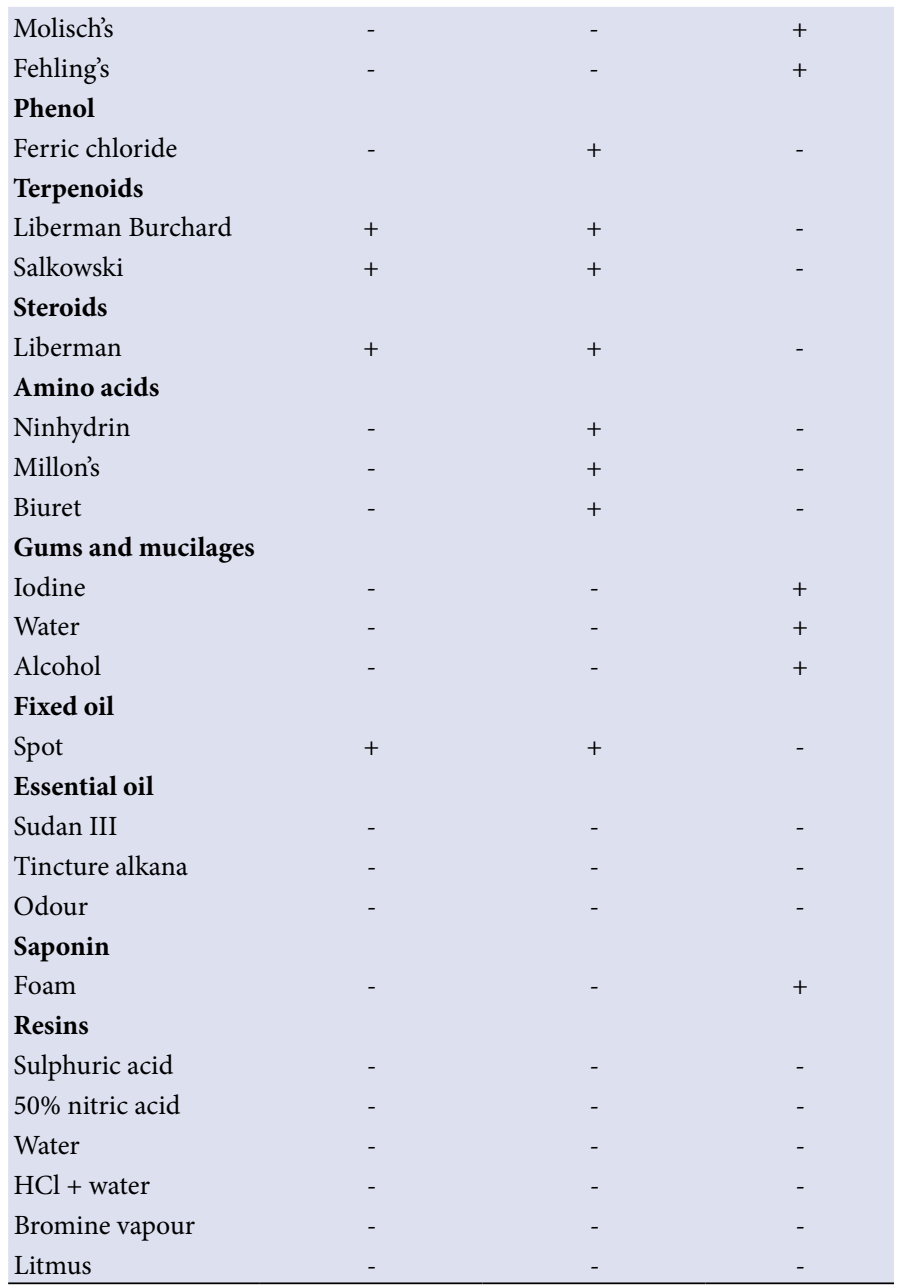

+ Present, - Absent

Table 3: TLC behavior of different extracts from leaves of VN.

\begin{tabular}{|c|c|c|c|}
\hline Extracts & Solvent system & No. of spots & $R_{f}$ values \\
\hline Cyclohexane & & 3 & $0.97,0.96,0.66$ \\
\hline Chloroform & & 9 & $\begin{array}{c}0.13,0.18,0.21 \\
0.28,0.36,0.41 \\
0.53,0.69,0.93\end{array}$ \\
\hline Petroleum Ether & & 4 & $\begin{array}{c}0.15,0.38,0.57 \\
0.94\end{array}$ \\
\hline Chloroform & & 4 & $0.18,0.52,0.8,0.91$ \\
\hline Acetone & Toluene: Ethyl & 8 & $\begin{array}{c}0.06,0.14,0.22 \\
0.35,0.46,0.52 \\
0.86,0.93\end{array}$ \\
\hline Ethanol & $\begin{array}{c}\text { acetate: Formic } \\
\text { acid } \\
(8: 2: 0.2)\end{array}$ & 5 & $\begin{array}{c}0.21,0.34,0.48 \\
0.60,0.76\end{array}$ \\
\hline Methanol & & 10 & $\begin{array}{c}.09,0.15,0.21 \\
0.26,0.33,0.39 \\
0.44,0.74,0.57 \\
0.94\end{array}$ \\
\hline Ethyl acetate & & 4 & $\begin{array}{c}0.09,0.18,0.55 \\
0.88\end{array}$ \\
\hline Benzene & & 8 & $\begin{array}{c}0.06,0.15,0.25 \\
0.35,0.45,0.51 \\
0.58,0.87\end{array}$ \\
\hline
\end{tabular}

The $\mathrm{R}_{\mathrm{f}}$ value 0.21 confirms the presence of marker compound. 
Table 4. This study was performed to assess the greatest UV absorbance activity of different extracts, the extract showing the greatest intensity was thought to posses the more UV radiation absorbing capacity and which can further be used as a sunscreen protective agent in cosmetics.

\section{Behavior of VN leaves with different reagents}

Behavior of $\mathrm{VN}$ leaves powder with different reagents was evaluated to study its reaxtion and stability with that reagent. Stability studies e.g. solubility, hydrolysis and degradation were performed to interpret the amount of degradation by noticing some visual characters such as brown color showed complete degradation of the components as shown in Table 5 .

\section{Metal analysis}

The acid insoluble ash was taken and by means of the atomic absorption spectroscopic method the metal analysis of VN leaf powder was done. The metal analysis results obtained revealed that Iron $(\mathrm{Fe})$ was present in the highest amount (456) and calcium was present in the least amount (0.03). All the concentrations were expressed in ppm as shown in Table 6.

Table 4: Fluorescence behavior of different extracts from the leaves of VN.

\begin{tabular}{ccccc}
\hline S. No. & Extract & Visible light & Short UV light & Long UV light \\
\hline 1. & Cyclohexane & Greenish yellow & Yellowish green & Amber color \\
2. & Carbon tetrachloride & Dark yellowish & Dark purple & Purple \\
3. & Getroleum ether & Greenish yellow & Yellowish green & Amber \\
4. & Chloroform & Dark herbage green & Purple & Purple \\
5. & Acetone & Dark herbage green & Dark purple & Red \\
6. & Ethanol & Dark herbage & Dark herbage green & Purple \\
7. & Methanol & Dark herbage green & Dark purple & Purple \\
8. & Ethyl acetate & Herbage green & Dark purple & Red \\
9. & Water & Brown & Blood color & Blood color \\
10. & Benzene & Dark herbage green & Purple & Purple \\
\hline
\end{tabular}

Table 5: Behaviour of VN powder with different reagents.

\begin{tabular}{|c|c|c|}
\hline S.No. & Chemical reagent & Observations \\
\hline 1. & Conc. sulphuric acid & Particles float on surface, brown in color \\
\hline 2. & Conc. Hydrochloric acid & $\begin{array}{c}\text { Particles float on surface, on shaking particles remain suspended, } \\
\text { brown in color }\end{array}$ \\
\hline 3. & Conc. Nitric acid & $\begin{array}{l}\text { Particles float on surface, on shaking particles remain suspended, rust } \\
\text { in color, thick consistency }\end{array}$ \\
\hline 4. & Acetic acid & $\begin{array}{l}\text { Particles float on surface, slowly settle, on shaking particles remains } \\
\text { suspended, brown in color }\end{array}$ \\
\hline 5. & Sodium hydroxide & $\begin{array}{l}\text { Particles float on surface, slowly settle, on shaking particles remains } \\
\text { suspended, amber in color }\end{array}$ \\
\hline 6. & Potassium hydroxide & $\begin{array}{c}\text { Particles float on surface, slowly settle, on shaking particles remain } \\
\text { suspended, amber in colour. }\end{array}$ \\
\hline 8. & Ferric Chloride & $\begin{array}{c}\text { Particles float on surface, amber in colour, on shaking particles remain } \\
\text { suspended. }\end{array}$ \\
\hline 9. & Iodine & $\begin{array}{l}\text { Particles float on surface, slowly settle, on shaking particles remain } \\
\text { suspended, yellowish brown in colour. }\end{array}$ \\
\hline 10. & Organoleptic characters & Colour: Dark green, Odour: odourless, Taste: Tasteless, Touch: soft. \\
\hline
\end{tabular}

Table 6: Metal analysis of VN.

\begin{tabular}{ccc}
\hline S.No. & Metals & Leaf \\
\hline 1. & $\mathrm{~N}^{*}$ & 0.98 \\
2. & $\mathrm{P}_{2} \mathrm{O}_{5}{ }^{*}$ & 0.17 \\
3. & $\mathrm{~K}_{2} \mathrm{O}^{*}$ & 0.40 \\
4. & $\mathrm{Ca}^{*}$ & 0.03 \\
5. & $\mathrm{Mg}^{*}$ & 0.51 \\
6. & $\mathrm{Zn}^{* *}$ & 78.0 \\
7. & $\mathrm{Cu}^{* *}$ & 37.0 \\
8. & $\mathrm{Fe}^{* *}$ & 456 \\
9. & $\mathrm{Mn}^{* *}$ & 87.0 \\
\hline
\end{tabular}

${ }^{\star}$ Values are in percentage, ${ }^{*}$ Values are in ppm 


\section{CONCLUSION}

The result from this study will prove to be very helpful while making any formulation of $\mathrm{VN}$.

\section{ACKNOWLEDGEMENT}

I would like to Thank UGC and Dr. Ajay Sharma for his cooperation and providing the working facilities for the research work.

\section{REFERENCES}

1. Gautam LN, Shreshtha SL, Wagle P, Tamrakar BM. Chemical constituents from vitex negundo Linn of Nepalese origin. Sci worl. 2008;6(6):27-32.

2. Das B, Das R. Medicinal properties and chemical constituents of Vitex negundo Linn. Ind Drug. 1994;31:431-5.

3. Singh V, Dayal R, Bartley JP. Volatile constituents of Vitex negundo leaves. Plant Med. 1999;65 (6):580-2

4. Dharmasiri MG, Jayakody AC, Galhena G, Liyanage SSP, Ratansooriya WD. Antiinflammatory and analgesic activities of mature fresh leaves of Vitex negundo. J Ethnopharmacol. 2003;87(2-3):199-206.

5. Tandon VR, Gupta RK. Vitex negundo Linn. (VN) leaf extract as an adjuvant therapy to standard anti-inflammatory drugs. Ind J Med Res. 2006;124(4):44750.

6. Tandon VR, Gupta RK. Anti-inflammatory activity and mechanism of action of Vitex negundo Linn. Int J Pharmacol. 2006;2(3):303-8.

7. Devi PR, Kumari SK, Kokilavani C. Effects of Vitex negundo leaf extracts on free radical scavengers in complete freund's adjuvant induced arthritic rats. Ind J Clinical biochem. 2007;22(1):143-7.

8. Panda SK, Thatoi HN, Dutta SK. Antibacterial activity and phytochemical screening of leaf and bark extracts of Vitex negundo Linn. from similipal biosphere reserve, Orissa. J Med Plant Res. 2009;3(4):294-300.

9. US patent- 7259148. Hepatoprotective activity of 2'- p-hydroxybenzoyl mussaenosidic acid.

10. Sheikh AT, Kaiser PJ, Gupta BD, Gupta VK, Johri RK. Negundoside, an irridoid glycoside from the leaves of vitex negundo, protects human liver cells against calcium mediated toxicity induced by carbon tetrachloride. World J Gastroenterol. 2008;14(23):3693-709.
11. Raj PV, Chandresekhar HR, Vijayan P, Dhanraj SA, Raol CA, Raol JV et al. In vitro and in-vivo hepatoprotective effect of Vitex negundo leaves. Pharmacologyonline. 2008;3:281-29.

12. Banerjee A, Vaghasiya R, Shrivastava N, Padh H, Nivsarkar M. Endometrial membrane response in Mus musculus during implantation by Vitex negundo Linn. Anim Rep. 2007;4(1):46-50.

13. Adnaik RS, Pai PT, Mule SN, Naikwade NS, Magdum CS. Laxative activity of Vitex negundo Linn leaves. Asian J Exp Sci. 2008;22(1):159-60.

14. Rooban BN, Lija Y, Biju PG, Sasikala V, Sahasranamam V, Abrahm V. Vitex negundo attenuates calpain activation and catractogenesis in selenite models. Exp Eye Res.

15. Karunamoorthi K, Ramanujam S, Rathinasamy R. Evaluation of leaf extracts of Vitex negundo L. against larvae of Culex tritaaeniorhynchus and repellant activity on adult vector mosquitoes. Parasitol Res. 2008;103(3):545-50.

16. Patel JP, Hemavathi KG, Bhatt JD. Effect of Vitex negundo on oxidative stress. Ind J Pharmacol. 2005;37(1):37-45.

17. Tamhankar $\mathrm{CP}$, Saraf MN. Anti-arthritic activity of Vitex negundo Linn. Ind $J$ Pharmaceutic Sci. 1994;56(1):158-9.

18. Gupta M, Mazumdar CK, Bhaval K. CNS activity of Vitex negundo Linn in mice. Ind J Exp Biol. 1999;37(2):143-6.

19. Alam MI, Gomes A. Snake venom neutralization by Indian medicinal plants (Vitex negundo and Embllica officinalis) root extracts. J Ethopharmacol. 2003;86(1):75-80.

20. Akerele A: WHO guidelines for assessment of herbal medicines. Fitoterapia 1992;62:99.

21. Indian herbal pharmacopeia, I and II, RRL, Jammu Tawi and IDMA, Mumbai India, 1998.

22. Chase CR. Fluoroscence of powdered vegetable drugs vegetable drugs with particular reference to development of a system of identification. J Am Pharmacol Assoc. 1949:38:32.

23. Kokoski CJ, Kokoski RJ, Slama FJ. Fluoroscence of powdered vegetable drugs under ultraviolet radiation. J Am Pharmacol Assoc. 1958;47:715.

24. Kokate CK. Practical Pharmacognosy, $13^{\text {th }}$ edition. Nirali Prakashan, Pune, 2003;197.

25. Harborne JB. Methods of extraction and isolation. London: Chapman and Hall. 1998;60-6

26. Sharma K, Bhatia S, Sharma A, Shinde V, Mahadik KR. Antioxidant activity of methanol extracts of Vitex negundo Linn. Pharmacologyonline. 2010;2:975-86.

\section{GRAPHICAL ABSTRACT}

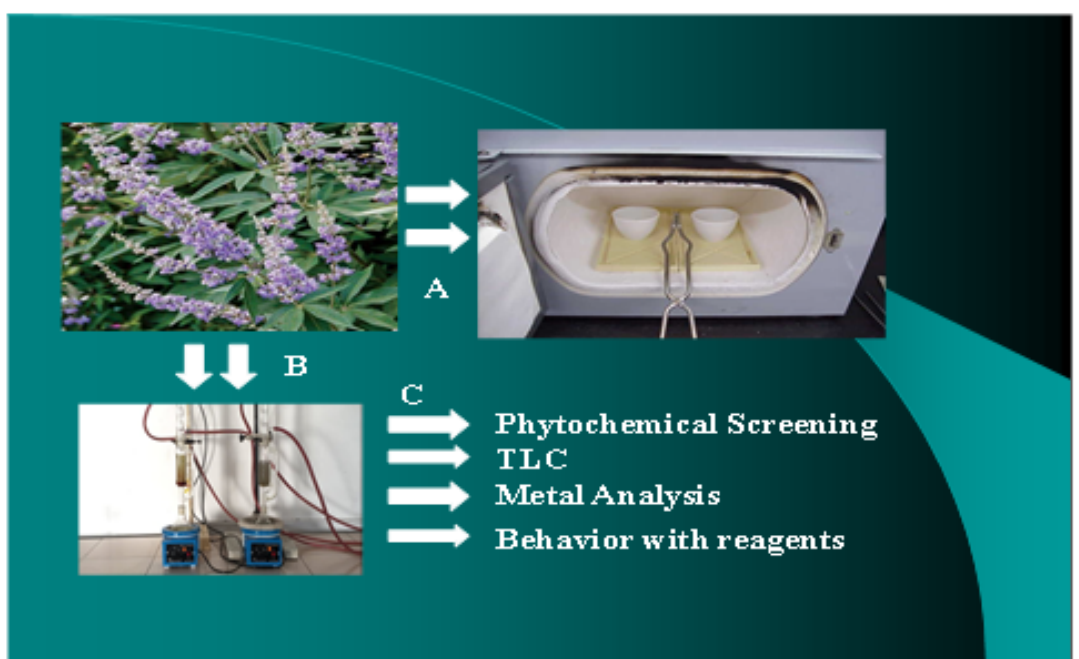
A- Determination of ash values from Vitex negundo plant
B- Extraction of Vitex negundo using solvents of different polarities
C- Pharmacognostical studies on the extracts. 


\section{ABOUT AUTHORS}

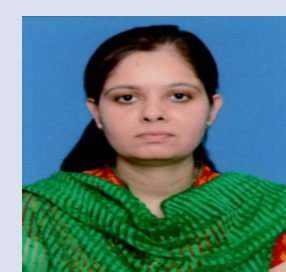

Dr. Kiran Sharma has started studying phytochemistry \& pharmacognosy at post-graduate level and has performed the characterization and evaluation of various active components from several medicinal plants. Her area of research is plant tissue culture and herbal drug standardization, where she has done studies on genetic transformation of Taraxacum officinale. She has also worked on latest techniques of plant biotechnology such as use of biotic and abiotic elicitors for increasing the yield of various phytoconstituents such as taraxerol and taraxasterol which are known to be potent anti-cancer compounds. She has to her credit around 12 publicatios in indexed journals and a book on plant biotechnology in pipeline.

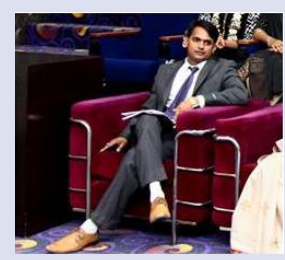

Dr. Manish Yadav has started studying pharmaceutics at post-graduate level and has performed the designed, development, characterization and evaluation of various dosage forms. His area of research is floating drug delivery system and solubility studies with techniques of enhancement of solubility of poorly soluble active pharmaceutical ingredients. He worked in Ranbaxy Research Laboratory in oral control release system (OCRS) in NDDS department and have experience of pharmacovigilance in Research and analysis (R\&A). He has also worked on latest techniques of Novel drug delivery systems. He has to his credit around 12 publications in indexed journals and a book on physical pharmacy in pipeline.

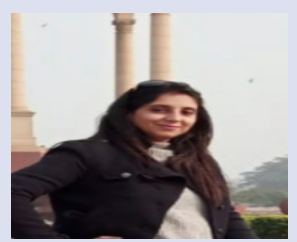

Ms. Kavita Attri has started studying Pharmaceutics at post-graduate level and has performed the Design, development \& characterization and evaluation of various formulations. She has also worked on latest techniques of novel drug delivery systems such as Transdermal drug delivery system and process validation of Glimipride. She has to her credit around 05 publications in indexed journals and a book on pharmaceutical technology in pipeline.

Cite this article: Sharma K, Yadav M, Attri K. Pharmacognostic Studies on Methanolic Extract of Leaves of Vitex negundo Linn. Pharmacog J. 2020;12(3):551-6. 